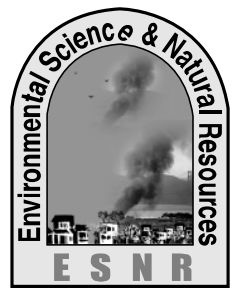

J. Environ. Sci. \& Natural Resources, 6(2): 115- 120,2013

ISSN 1999-7361

\title{
Effect of Fertilizers on the Yield and Nutrient Uptake by Transplanted Aman Rice (Binadhan-7) Grown in Two Soils of North-West Bangladesh M. M. Ali, M. H. Rahman, M. R. Khan and M. K. Khan
}

Soil Science Division

Bangladesh Institute of Nuclear Agriculture, Mymensingh

\begin{abstract}
Four field experiments were carried out with Binadhan 7 at Birgonj, Dinajpur; Debigonj, Panchagarh; Kaligonj, Lalmonirhat and Pirgonj, Rangpur during T.aman (kharif II) season of 2011 in the Old Himalalayan Piedmont Plain (AEZ 1) and Tista Meander Floodplain Soils of North-West Bangladesh. The experiments were designed with eight treatments and laid out in randomized complete block design (RCBD) with three replications. The treatment combinations were: $\mathrm{T}_{1}(100 \% \mathrm{STB}), \mathrm{T}_{2}\left(\mathrm{~T}_{1}+\right.$ $25 \% \mathrm{~N}), \mathrm{T}_{3}\left(\mathrm{~T}_{1}+25 \% \mathrm{NP}\right), \mathrm{T}_{4}\left(\mathrm{~T}_{1}+25 \% \mathrm{NK}\right), \mathrm{T}_{5}\left(\mathrm{~T}_{1}+25 \% \mathrm{PK}\right), \mathrm{T}_{6}\left(\mathrm{~T}_{1}+25 \% \mathrm{NPK}\right), \mathrm{T}_{7}\left(75 \%\right.$ of $\left.\mathrm{T}_{1}\right)$ and $\mathrm{T}_{8}$ (Control). Results indicated that application of different fertilizers significantly affected the grain yield at all of the four locations. The highest grain yield was found in treatment $\mathrm{T}_{6}\left(\mathrm{~T}_{1}+25 \% \mathrm{NPK}\right)$. Statistically identical yield was observed in treatments $\mathrm{T}_{3}, \mathrm{~T}_{4}$ and $\mathrm{T}_{5}$ at Dinajpur; $T_{3}$ at Panchagar; $T_{2}, T_{3}$, and $T_{4}$ at Lalmonirhat and $T_{2}$ at Rangpur. All the treatment combinations gave significantly higher grain yield over the control at all of the locations. The highest straw yield was found in treatment $\mathrm{T}_{6}\left(\mathrm{~T}_{1}+25 \% \mathrm{NPK}\right.$. Statistically identical straw yield was found in $T_{3}$ and $T_{4}$ at Dinajpur; $T_{1}, T_{4}$ and $T_{5}$ at Panchagar; $T_{2}, T_{4}, T_{5}$ and $T_{7}$ Lalmonirhat and all treatments except $\mathrm{T}_{7}$ and $\mathrm{T}_{8}$ at Rangpur. Significantly the lowest yield was obtained in the control treatment $\left(\mathrm{T}_{8}\right)$ in all of the locations. The highest total $\mathrm{N}$ uptake was observed in treatment $\mathrm{T}_{6}$ at all of the four locations. For total $\mathrm{P}$ uptake, the similar trend of total $\mathrm{N}$ uptake was observed for all the locations. Treatment $\mathrm{T}_{6}$ showed the highest uptake of total $\mathrm{K}$ at all locations. The highest uptake of total $\mathrm{S}$ was observed in treatment $\mathrm{T}_{6}$ at Dinajpur, Panchagarh and Lalmonirhat. But the highest uptake of total $\mathrm{S}$ was observed in treatment $\mathrm{T}_{3}$ at Rangpur. However, the lowest total N, P, K and S uptake was observed in control treatment $\left(\mathrm{T}_{8}\right)$ at all locations. The partial budget analysis of T.aman rice demonstrated the highest net benefit of tkha ${ }^{-1} 85,598 /-, 78,619 /-$, $58,308 /-$ and $72,532 /-$ in $\mathrm{T}_{6}$ treatment followed by tkha ${ }^{-1} 76,348 /-$ in $\mathrm{T}_{4}$ treatment, $71,100 /-$ in $\mathrm{T}_{3}$ treatment, 54,192/- in $\mathrm{T}_{3}$ treatment and 68,247/- in $\mathrm{T}_{2}$ treatment where the highest MBCR of 5.40, 3.75, 2.20 and 3.84 was also observed in $\mathrm{T}_{6}$ treatment at Dinajpur, Panchagarh, Lalmonirhat and Rangpur, respectively. Based on most profitable treatments, fertilizer doses of $\mathrm{N}_{80} \mathrm{P}_{8} \mathrm{~K}_{40} \mathrm{~S}_{8} \mathrm{Zn}_{1}$ in Birgonj, Dinajpur; $\mathrm{N}_{84} \mathrm{P}_{8} \mathrm{~K}_{40} \mathrm{~S}_{6} \mathrm{Zn}_{1}$ in Debigonj, Panchagarh; $\mathrm{N}_{80} \mathrm{P}_{8} \mathrm{~K}_{40} \mathrm{~S}_{6} \mathrm{Zn}_{1}$ in Kaligonj, Lalmonirhat and $\mathrm{N}_{81} \mathrm{P}_{8} \mathrm{~K}_{35} \mathrm{~S}_{8} \mathrm{Zn}_{1}$ in Pirgonj, Rangpur could be recommended for higher yield of Binadhan-7 rice in North-West Bangladesh.
\end{abstract}

Key words: Fertilizers, Binadhan-7, Yield, Kharif II season and North-West Bangladesh.

\section{Introduction}

The soil fertilizer system in modern agriculture is getting more and more systematic and technical throughout the world. Application of imbalanced chemical fertilizers, non-recycling of organic matter to soil, continued cultivation of HYV crops, inadequate management practices etc. are associated with depletion of soil fertility in Bangladesh. A huge quantity of nutrients removed from most of the floodplains and large portion of the terrace soils with the intensification of agriculture in Bangladesh. As a result the level of soil fertility is diminishing gradually reflecting the needs of more fertilizer application in the soil for sustaining crop productivity. Deficiency of a number of macro and micro nutrients viz. nitrogen, phosphorus, potassium sulphur, zinc, boron and molybdenum etc. has already been reported from different parts of the country. Such deficiencies might be occurred due to inefficient fertilizer management by the farmers.

A sound soil testing program for rational and judicious fertilizer use to obtain desired crop response must be based on critical soil fertility limits of different nutrient elements in soil of the particular area. Soil testing has been recognized as an effective tool for determining fertilizer need of crop under all situations, and its importance is by far greatest practical value for fertilizers as scarce and costly commodity with respect to the farmers' investment ability.

Balanced fertilization in modern intensive high yielding cropping systems is prerequisite for the environment and sustaining agricultural production. Therefore, it is a challenge to develop environment friendly and economically suitable combinations of inorganic and organic fertilizers for sustaining soil fertility with higher crop productivity. Supplying adequate amounts of mineral nutrients to crops is one of the most important factors in achieving higher productivity (Fageria et al., 1991). The amount of nutrient taken up by a crop is closely related to the total amount of biomass it produces. In general, higher the yield level higher is the amount of nutrient removed by the crop (Bhuiyan, 1993).

Fertilizer is a key component in the agricultural production systems of Bangladesh. Its use efficiency is becoming much more important in the market economy of agriculture products. Present level of fertilizer use in farmers' fields shows under or over use of recommended fertilizer doses. It requires farm level investigation to find out reasons for such gap between the recommended doses and farmers' actual practices. It is, therefore, necessary for judicious 
application of fertilizers not only for increasing crop production but also maintaining soil fertility and environment.

\section{Materials and Methods}

\section{Description of the experimental sites}

Four field experiments were carried out at Birgonj, Dinajpur; Debigonj, Panchagarh; Kaligonj, Lalmonirhat and Pirgonj, Rangpur during T.aman (kharif II) season of 2011 using Binadhan-7 as test crop in the Old Himalalayan Piedmont Plain (AEZ 1) and Tista Meander Floodplain (AEZ 3) soils of North-West Bangladesh. The climatic condition of the experimental area is sub-tropical monsoon as prevailed in the other portion of the country.

\section{Collection and analysis of initial soil samples}

Initial soil samples were collected from the different experimental sites. After collecting soil sample, the unwanted materials like gravels, plant roots, leaves etc., were picked up and removed. Then the samples were air dried, well mixed and ground to pass through a 20 mesh sieve and stored in clean plastic bags for physical and chemical analysis. Soil samples were analyzed following standard methods, viz.: particle size distribution by a hydrometer, soil $\mathrm{pH}$ by glass electrode $\mathrm{pH}$ meter, organic matter by wet oxidation and total nitrogen by micro-Kjeldahl method, available phosphorus and available sulphur were extracted from soil by dilute acid solutions and determined by a spectrophotometer, exchangeable potassium was extracted with ammonium acetate solution and was determined by a flame photometer. The physico-chemical properties of the experimental soils are presented in Table 1.

Table 1. Initial soil characteristics of the soils under study

\begin{tabular}{|c|c|c|c|c|}
\hline Soil properties & Birgonj (Dinajpur) & Debigonj (Panchagarh) & Kaligonj (Lalmonirhat) & Pirgonj (Rangpur) \\
\hline Sand $(\%)$ & 61.6 & 63.6 & 59.4 & 43.6 \\
\hline Silt $(\%)$ & 22.0 & 20.0 & 24.0 & 30.0 \\
\hline Clay $(\%)$ & 16.4 & 16.4 & 16.4 & 26.4 \\
\hline Texture & Sandy loam & Sandy loam & Sandy loam & Loam \\
\hline $\mathrm{pH}$ & 5.4 & 5.4 & 5.3 & 5.6 \\
\hline $\mathrm{OM}(\%)$ & 1.74 & 1.20 & 1.74 & 1.35 \\
\hline $\mathrm{TN}(\%)$ & 0.087 & 0.060 & 0.087 & 0.068 \\
\hline Avail. P (ppm) & 25.5 & 16.6 & 31.6 & 20.1 \\
\hline Avail. S (ppm) & 12.0 & 21.9 & 19.1 & 11.2 \\
\hline Exch. K (me\%) & 0.09 & 0.09 & 0.11 & 0.13 \\
\hline
\end{tabular}

Collection and analysis of grain and straw samples Grain and straw samples were collected during harvesting period. Grain and straw samples were dried in an oven at about $65^{\circ} \mathrm{C}$ for 48 hours and then ground in a grinding mill to pass through a 20 mesh sieve. The ground grain and straw samples were stored in small paper bags and placed in desiccators for the analysis of different elements. The grain and straw samples were analyzed for the determination of $\mathrm{N}, \mathrm{P}, \mathrm{K}$ and $\mathrm{S}$ contents.

An amount of $0.5 \mathrm{~g}$ of oven dried ground plant sample was taken in a micro-kjeldahl flask. Then 1.1 $\mathrm{g}$ of catalyst mixture $\left(\mathrm{K}_{2} \mathrm{SO}_{4}: \mathrm{CUSO}_{4}: 5 \mathrm{H}_{2} \mathrm{O}: \mathrm{Se}\right.$ powder =100: 10: 1), $3 \mathrm{ml}$ of $30 \% \mathrm{HClO}_{4}$ and $5 \mathrm{ml}$ of conc. $\mathrm{H}_{2} \mathrm{SO}_{4}$ were added in the flask. The flask was swirled and allowed to stand for about 1.5-2 hours. Then the flask was heated on an electric hot plate for heating at $150^{\circ} \mathrm{C}$ and continued until the digest become colorless. After cooling the digest was transferred into a $100 \mathrm{ml}$ volumetric flask and the volume was made up to the mark wide distilled water. A reagent blank was prepared similarly. From the digests, nitrogen was determined.

An amount of $0.5 \mathrm{~g}$ oven-dry, ground samples (straw and grain) was taken in a digestion flask. $8 \mathrm{ml}$ of diacid mixture $\left(\mathrm{HNO}_{3}: \mathrm{HClO}_{4}\right.$ in the ratio 5:3) was added into flask and kept for 1 hour. Then the flask was heated on an electric hot plate for heating at $150^{\circ}$ $\mathrm{C}$ and continued until the digest become colorless. After cooling the digest was transferred into a $50 \mathrm{ml}$ volumetric flask and the volume was made up to mark with distilled water. From the digests, plant $\mathrm{P}, \mathrm{K}$ and $\mathrm{S}$ were determined.

\section{Transplanting, fertilization and intercultural operations}

The land was well prepared before transplantation. After uniformly leveling, the experimental plots were laid out in randomized complete block design (RCBD) with three replications. The unit plots area was $5 \mathrm{mx} 4 \mathrm{~m}$. Eight treatment combinations of fertilizers were used in the experiments. The sources of $\mathrm{N}, \mathrm{P}, \mathrm{K}, \mathrm{S}$ and $\mathrm{Zn}$ were urea, TSP, MoP, gypsum and zinc oxide, respectively. Three healthy seedlings of Binadhan-7 rice of 25-30 days old were transplanted per hill in the plots. Fertilizers were applied to each plot as per treatment. The full dose of all fertilizers except urea was applied as basal to each individual plots during final land preparation. The fertilizers were incorporated into the soils. The first split (1/3) of $\mathrm{N}$ was applied within 10 days after transplanting. The second split (1/3) of $\mathrm{N}$ was applied at maximum vegetative growth stage and incorporated 
with the soil. The third split (1/3) of $\mathrm{N}$ was applied at or before P.I. stages. Pest control and other intercultural practices like irrigation, etc. were given as and when necessary.

\section{Statistical analysis}

The recorded data were compiled and tabulated properly. The recorded data were statistically analyzed to find out the significance of variance resulting from the experimental treatments on various plant characters. Analysis of Variance (ANOVA) was done following RCBD with the help of a computer package program MSTAT and mean differences were adjudged by Duncan's Multiple Range Test (Gomez and Gomez, 1984).

\section{Results and Discussion}

\section{Yield contributing characters}

Results of plant height, panicle length, number of tillers per hill and 1000 grain weight were recorded and the data are shown in Table $2 \mathrm{a}$ to Table $2 \mathrm{~b}$. Plant height of Binadhan-7 was significantly influenced by the fertilizer treatments. It revealed that all the treatments produced significantly taller plants compared to the control treatment $\left(\mathrm{T}_{1}\right)$ at all the locations. However, the plant height ranged from 93.3 to $99.9 \mathrm{~cm}$ at Birgonj, Dinajpur; 80.2 to $91.3 \mathrm{~cm}$ at Debigonj, Panchagarh; 82.6 to $92.5 \mathrm{~cm}$ at Kaligonj, Lalmonirhat and 89.1 to $99.3 \mathrm{~cm}$ at Pirgonj, Rangpur. The plant height was comparatively taller at Birgonj and Pirgonj than that was observed at Debigonj and Kaligonj. These variations in plant height might be due to the local variations in soil characteristics along with the interactions of the different fertilizer nutrients. The different treatment combinations of fertilizers significantly influenced the panicle length of Binadhan7. However, the panicle length was found more or less identical at all the locations. The lowest panicle length was observed in treatment $T_{1}$ (control). Like Plant height and panicle length, the number of effective tillers per hill was significantly influenced by the fertilizer treatments. However, the higher number of tillers was observed at Birgonj and Debigonj than that was observed at Kaligonj and Pirgonj. These variations in number of tillers per hill also might be due to the local variations in soil characteristics with the interactions of the different fertilizer nutrients. There was no significant effect of different fertilizer treatment combinations was observed in the case of 1000-grain weight of Binadhan-7 grown at four locations in North-West Bangladesh. However, the 1000 grain weight was found lowest in treatment $T_{1}$ (control) at all the locations. Similar results of plant height, panicle length, number of effective tillers per hill and 1000 grain weight were also reported by Jadhav et al. (2006), Rahman et al. (2007), Islam et al. (2008).

Table 2a. The effects of different treatments on plant height, panicle length, tillers hill ${ }^{-1}$ and 1000 seed weight of Binadhan 7 at Birgonj, Dinajpur and Debigonj, Panchagar

\begin{tabular}{|c|c|c|c|c|c|c|c|c|}
\hline \multirow[t]{2}{*}{ Treatments } & \multicolumn{4}{|c|}{ Birgonj, Dinajpur } & \multicolumn{4}{|c|}{ Debigonj, Panchagar } \\
\hline & $\begin{array}{l}\text { Plant height } \\
(\mathrm{cm})\end{array}$ & $\begin{array}{l}\text { Panicle length } \\
(\mathrm{cm})\end{array}$ & $\begin{array}{l}\text { Tillers/hill } \\
\text { (No.) }\end{array}$ & $\begin{array}{l}1000 \text { seed wt. } \\
(\mathrm{gm})\end{array}$ & $\begin{array}{l}\text { Plant height } \\
(\mathrm{cm})\end{array}$ & $\begin{array}{l}\text { Panicle length } \\
(\mathrm{cm})\end{array}$ & $\begin{array}{c}\text { Tillers/hill } \\
\text { (No.) }\end{array}$ & $\begin{array}{c}1000 \text { seed } \\
\text { wt. (gm) }\end{array}$ \\
\hline$\overline{\mathrm{T}_{1}\left(100 \% \mathrm{STB}^{*}\right)}$ & $99.13 \mathrm{a}$ & $23.47 \mathrm{a}$ & $09.73 d$ & 23.93 & $85.73 c$ & $22.20 \mathrm{abc}$ & $10.27 \mathrm{~cd}$ & 22.52 \\
\hline $\mathrm{T}_{2}\left(\mathrm{~T}_{1}+25 \% \mathrm{~N}\right)$ & $97.80 \mathrm{ab}$ & $23.07 \mathrm{ab}$ & $12.47 \mathrm{a}$ & 22.89 & $87.53 b c$ & $23.07 \mathrm{ab}$ & $10.20 \mathrm{~cd}$ & 20.91 \\
\hline $\mathrm{T}_{3}\left(\mathrm{~T}_{1}+25 \% \mathrm{NP}\right)$ & $98.00 \mathrm{ab}$ & $22.27 \mathrm{bc}$ & $10.53 \mathrm{c}$ & 24.17 & $88.33 \mathrm{abc}$ & $22.27 \mathrm{abc}$ & $11.40 \mathrm{bc}$ & 20.95 \\
\hline $\mathrm{T}_{4}\left(\mathrm{~T}_{1}+25 \% \mathrm{NK}\right)$ & $96.40 \mathrm{~b}$ & $23.13 \mathrm{ab}$ & $10.67 \mathrm{c}$ & 23.47 & $91.27 \mathrm{a}$ & $23.17 \mathrm{a}$ & $11.00 \mathrm{ab}$ & 21.77 \\
\hline $\mathrm{T}_{5}\left(\mathrm{~T}_{1}+25 \% \mathrm{PK}\right)$ & $99.27 \mathrm{a}$ & $24.00 \mathrm{a}$ & $10.00 \mathrm{~cd}$ & 24.16 & $85.20 \mathrm{c}$ & $22.93 \mathrm{ab}$ & $11.93 \mathrm{ab}$ & 21.62 \\
\hline $\mathrm{T}_{6}\left(\mathrm{~T}_{1}+25 \% \mathrm{NPK}\right)$ & $99.93 \mathrm{a}$ & $23.40 \mathrm{a}$ & $10.53 \mathrm{c}$ & 23.22 & $90.67 \mathrm{ab}$ & $22.07 \mathrm{abc}$ & $12.33 \mathrm{a}$ & 21.55 \\
\hline $\mathrm{T}_{7}\left(75 \%\right.$ of $\left.\mathrm{T}_{1}\right)$ & $98.27 \mathrm{ab}$ & $23.33 \mathrm{a}$ & $09.53 d$ & 23.65 & $88.33 \mathrm{abc}$ & $21.87 \mathrm{bc}$ & $10.33 \mathrm{~cd}$ & 20.28 \\
\hline $\mathrm{T}_{8}$ (Control) & $93.33 \mathrm{c}$ & $21.53 c$ & $11.67 b$ & 22.64 & $80.20 \mathrm{~d}$ & $21.53 c$ & $09.67 \mathrm{~d}$ & 21.22 \\
\hline CV $(\%)$ & 1.25 & 2.44 & 3.60 & 0.486 & 2.02 & 2.94 & 4.74 & 0.03 \\
\hline
\end{tabular}

and Pirgonj, Rangpur: $\mathrm{T}_{1}=\mathrm{N}_{65} \mathrm{P}_{6} \mathrm{~K}_{28} \mathrm{~S}_{8} \mathrm{Zn}_{1}$.

Table 2b. The effects of different treatments on plant height, panicle length, tillers hill ${ }^{-1}$ and 1000 seed weight of Binadhan 7 at Kaligonj, Lalmonirhat and Pirgonj, Rangpur

\begin{tabular}{|c|c|c|c|c|c|c|c|c|}
\hline \multirow[t]{2}{*}{ Treatments } & \multicolumn{4}{|c|}{ Kaligonj, Lalmonirhat } & \multicolumn{4}{|c|}{ Pirgonj, Rangpur } \\
\hline & $\begin{array}{l}\text { Plant height } \\
(\mathrm{cm})\end{array}$ & $\begin{array}{c}\text { Panicle } \\
\text { length }(\mathrm{cm})\end{array}$ & $\begin{array}{c}\text { Tillers } \\
\text { hill }^{-1} \text { (No.) }\end{array}$ & $\begin{array}{l}1000 \text { seed } \\
\text { wt. }(\mathrm{gm})\end{array}$ & $\begin{array}{l}\text { Plant height } \\
(\mathrm{cm})\end{array}$ & $\begin{array}{c}\text { Panicle } \\
\text { length }(\mathrm{cm})\end{array}$ & $\begin{array}{l}\text { Tillers hill }^{-1} \\
\text { (No.) }\end{array}$ & $\begin{array}{l}1000 \text { seed } \\
\text { wt. (gm) }\end{array}$ \\
\hline $\mathrm{T}_{1}(100 \% \mathrm{STB} *)$ & $91.93 \mathrm{~b}$ & 24.87 & $08.33 \mathrm{ab}$ & 21.74 & $96.40 \mathrm{ab}$ & $24.67 \mathrm{a}$ & $08.73 a$ & 22.57 \\
\hline $\mathrm{T}_{2}\left(\mathrm{~T}_{1}+25 \% \mathrm{~N}\right)$ & $89.67 b$ & 24.13 & $08.27 \mathrm{ab}$ & 21.37 & $97.33 \mathrm{ab}$ & $24.13 \mathrm{ab}$ & $08.60 \mathrm{a}$ & 23.10 \\
\hline $\mathrm{T}_{3}\left(\mathrm{~T}_{1}+25 \% \mathrm{NP}\right)$ & $91.87 \mathrm{~b}$ & 24.20 & $08.27 \mathrm{ab}$ & 22.08 & $99.33 \mathrm{a}$ & $24.67 \mathrm{a}$ & $07.60 \mathrm{bc}$ & 23.20 \\
\hline $\mathrm{T}_{4}\left(\mathrm{~T}_{1}+25 \% \mathrm{NK}\right)$ & $97.67 \mathrm{a}$ & 24.67 & 09.00a & 21.91 & $97.47 \mathrm{ab}$ & $24.53 \mathrm{a}$ & $08.73 a$ & 23.18 \\
\hline $\mathrm{T}_{5}\left(\mathrm{~T}_{1}+25 \% \mathrm{PK}\right)$ & $90.13 b$ & 24.47 & $08.13 \mathrm{ab}$ & 22.01 & $96.60 \mathrm{ab}$ & $24.93 \mathrm{a}$ & $08.13 \mathrm{ab}$ & 23.13 \\
\hline $\mathrm{T}_{6}\left(\mathrm{~T}_{1}+25 \% \mathrm{NPK}\right)$ & $92.53 b$ & 24.40 & $08.87 \mathrm{ab}$ & 21.93 & $96.47 \mathrm{ab}$ & $24.20 \mathrm{ab}$ & 08.60a & 23.02 \\
\hline $\mathrm{T}_{7}\left(75 \%\right.$ of $\left.\mathrm{T}_{1}\right)$ & $90.33 b$ & 24.93 & $07.47 \mathrm{bc}$ & 22.00 & $95.60 \mathrm{~b}$ & $24.27 \mathrm{a}$ & $08.47 \mathrm{a}$ & 22.39 \\
\hline $\mathrm{T}_{8}$ (Control) & $82.60 \mathrm{c}$ & 23.47 & $06.27 \mathrm{c}$ & 20.92 & $89.07 \mathrm{c}$ & $23.33 b$ & $07.40 \mathrm{c}$ & 21.89 \\
\hline $\mathrm{CV}(\%)$ & 2.5 & 2.33 & 9.49 & 0.74 & 1.74 & 1.98 & 4.56 & 0.46 \\
\hline
\end{tabular}

\footnotetext{
- $\mathrm{STB}=$ Same as in Table 2a
} 


\section{Grain and straw yield}

Results indicated that grain yield of Binadhan-7 rice was significantly affected by the application of different fertilizers (Table 3 ). The highest grain yield was found in treatment $\mathrm{T}_{6}\left(\mathrm{~T}_{1}+25 \% \mathrm{NPK}\right)$. Statistically identical yield was observed in treatments $T_{3}, T_{4}$ and $T_{5}$ at Birgonj, Dinajpur; $T_{3}$ at Debigonj, Panchagar; $T_{2}, T_{3}$, and $T_{4}$ at Kaligonj, Lalmonirhat and $\mathrm{T}_{2}$ at Pirgonj, Rangpur. All the treatment combinations gave significantly higher grain yield over the control at all of the four locations. Similar results were also reported earlier by Annadurai et al. (2000).
Straw yield of Binadhan-7 was also significantly influenced by the different combinations of fertilizer treatments (Table 3). The highest straw yield was found in treatment $\mathrm{T}_{6}\left(\mathrm{~T}_{1}+25 \% \mathrm{NPK}\right)$. Statistically identical yield was found in $T_{3}$ and $T_{4}$ at Birgonj, Dinajpur; $\mathrm{T}_{1}, \mathrm{~T}_{4}$ and $\mathrm{T}_{5}$ at Debigonj, Panchagar; $\mathrm{T}_{2}$, $\mathrm{T}_{4}, \mathrm{~T}_{5}$ and $\mathrm{T}_{7}$ at Kaligonj, Lalmonirhat and all treatments except $T_{7}$ and $T_{8}$ at Pirgonj, Rangpur. Significantly the lowest yield was obtained in the control treatment $\left(\mathrm{T}_{8}\right)$ in all of the locations. Similar result was recorded by Singh et al. (2000) who observed that inorganic fertilizer combinations encouraged vegetative growth and thereby increased straw yield.

Table 3. Effects of fertilizers on yield of T. aman rice (Binadhan-7) during Kharif-II season, 2011at Birgonj, Dinajpur; Debigonj, Panchagar; Kaligonj, Lalmonirhat and Pirgonj, Rangpur

\begin{tabular}{|c|c|c|c|c|c|c|c|c|}
\hline \multirow[t]{2}{*}{ Treatments } & \multicolumn{2}{|c|}{ Birgonj, Dinajpur } & \multicolumn{2}{|c|}{ Debigonj, Panchagar } & \multicolumn{2}{|c|}{ Kaligonj, Lalmonirhat } & \multicolumn{2}{|c|}{ Pirgonj, Rangpur } \\
\hline & Grain & Straw & Grain & Straw & Grain & Straw & Grain & Straw \\
\hline \multicolumn{9}{|c|}{$\mathrm{tha}^{-1}$} \\
\hline $\mathrm{T}_{1}(100 \% \mathrm{STB} *)$ & $3.93 \mathrm{c}$ & $4.53 c$ & $4.07 \mathrm{~cd}$ & $6.30 \mathrm{ab}$ & $3.24 \mathrm{bcd}$ & $3.56 \mathrm{bc}$ & $4.14 c$ & $4.85 \mathrm{ab}$ \\
\hline $\mathrm{T}_{2}\left(\mathrm{~T}_{1}+25 \% \mathrm{~N}\right)$ & $4.37 \mathrm{bc}$ & $5.87 \mathrm{~b}$ & $4.30 \mathrm{bcd}$ & $6.03 \mathrm{~b}$ & $3.58 \mathrm{abc}$ & $4.40 \mathrm{ab}$ & $4.63 \mathrm{ab}$ & $5.12 \mathrm{a}$ \\
\hline $\mathrm{T}_{3}\left(\mathrm{~T}_{1}+25 \% \mathrm{NP}\right)$ & $5.03 \mathrm{ab}$ & $6.10 \mathrm{ab}$ & $4.80 \mathrm{ab}$ & $6.03 b$ & $3.81 \mathrm{ab}$ & $3.77 \mathrm{bc}$ & $4.37 \mathrm{bc}$ & $4.69 \mathrm{ab}$ \\
\hline $\mathrm{T}_{4}\left(\mathrm{~T}_{1}+25 \% \mathrm{NK}\right)$ & $5.13 \mathrm{ab}$ & $6.47 \mathrm{ab}$ & $4.23 \mathrm{bcd}$ & $6.73 \mathrm{ab}$ & $3.65 \mathrm{abc}$ & $4.27 \mathrm{ab}$ & $4.55 \mathrm{~b}$ & $5.19 \mathrm{a}$ \\
\hline $\mathrm{T}_{5}\left(\mathrm{~T}_{1}+25 \% \mathrm{PK}\right)$ & $4.93 \mathrm{ab}$ & $5.47 \mathrm{bc}$ & $4.37 \mathrm{bc}$ & $6.37 \mathrm{ab}$ & $3.31 \mathrm{bcd}$ & $3.95 \mathrm{ab}$ & $4.34 \mathrm{bc}$ & $4.69 \mathrm{ab}$ \\
\hline $\mathrm{T}_{6}\left(\mathrm{~T}_{1}+25 \% \mathrm{NPK}\right)$ & $5.72 \mathrm{a}$ & $7.07 \mathrm{a}$ & $5.27 \mathrm{a}$ & $6.90 \mathrm{a}$ & $4.05 \mathrm{a}$ & $4.72 \mathrm{a}$ & $4.97 \mathrm{a}$ & $5.06 \mathrm{a}$ \\
\hline $\mathrm{T}_{7}\left(75 \%\right.$ of $\left.\mathrm{T}_{1}\right)$ & $3.73 \mathrm{c}$ & $4.43 c$ & $3.67 \mathrm{de}$ & $4.83 c$ & $3.01 \mathrm{~cd}$ & $3.88 \mathrm{ab}$ & $3.45 \mathrm{~d}$ & $4.35 \mathrm{bc}$ \\
\hline $\mathrm{T}_{8}$ (Control) & $2.87 \mathrm{~d}$ & $3.27 \mathrm{~d}$ & $3.17 \mathrm{e}$ & $3.60 \mathrm{~d}$ & $2.64 \mathrm{~d}$ & $2.98 \mathrm{c}$ & $2.77 \mathrm{e}$ & $3.80 \mathrm{c}$ \\
\hline $\mathrm{CV}(\%)$ & 10.89 & & 8.49 & 6.53 & 10.71 & 11.42 & 4.97 & 7.48 \\
\hline
\end{tabular}

$* \mathrm{STB}=$ Same as in Table 2a.

\section{Total Nutrient uptake}

Both grain and straw of Binadhan-7 rice were analyzed for the determination of $\mathrm{N}, \mathrm{P}, \mathrm{K}$ and $\mathrm{S}$ concentrations. The total uptakes of these nutrients were also calculated from the yield and the nutrient concentration of grain and straw. The total nutrient uptake by Binadhan 7 at different locations was influenced due to different treatments (Table 4a to Table $4 \mathrm{~b}$ ). The highest total $\mathrm{N}$ uptake was observed in treatment $\mathrm{T}_{6}$ at all of the studied locations. Prudente et al. (2008) found approximately $1.4 \%$ increase in the total $\mathrm{N}$ uptake for every additional kilogram of applied $\mathrm{N} \mathrm{ha}^{-1}$. Phosphorus uptake by grain and straw were significantly influenced by the application of different levels of P (Sayeeduzzaman, 2008 and
Rahman, 2008). Treatment $T_{6}$ showed the highest uptake of total $\mathrm{K}$ at all locations. Nagarathna and Prakasha (2007) revealed that the application of potassium $60 \%$ as basal and $40 \%$ at maximum tiller stage significantly increased the total $\mathrm{K}$ uptake. The highest uptake of total $\mathrm{S}$ was observed in treatment $\mathrm{T}_{6}$ at Birgonj, Dinajpur; Debigonj, Panchagarh and Kaligonj, Lalmonirhat. But the highest uptake of total $S$ was observed in treatment $T_{3}$ at Pirgonj, Rangpur. However, the lowest total N, P, K and S uptake was observed in control treatment $\left(\mathrm{T}_{8}\right)$ at all locations. Uddin (2008) found that total S content and uptake by grain and straw were significantly influenced by the application of different levels of sulphur. 
Table 4a. Effects of fertilizers on total nutrient uptake ( $\mathrm{kg} / \mathrm{ha}$ ) by T. aman rice (Binadhan-7) during Kharif-II season, 2011 at Birgonj, Dinajpur and Debigonj, Panchagar

\begin{tabular}{|c|c|c|c|c|c|c|c|c|}
\hline \multirow[t]{2}{*}{ Treatments } & \multicolumn{4}{|c|}{ Birgonj (Dinajpur) } & \multicolumn{4}{|c|}{ Debigonj (Panchagarh) } \\
\hline & $\mathrm{N}$ & $\mathrm{P}$ & $\mathrm{K}$ & $S$ & $\mathrm{~N}$ & $\mathrm{P}$ & $\mathrm{K}$ & $S$ \\
\hline $\mathrm{T}_{1}=(100 \% \mathrm{STB} *)$ & 83 & 14.6 & 88 & 8.3 & 73 & 11.7 & 68 & 8.0 \\
\hline $\mathrm{T}_{2}=\mathrm{T}_{1}+25 \% \mathrm{~N}$ & 82 & 14.8 & 108 & 8.6 & 84 & 13.1 & 90 & 9.0 \\
\hline $\mathrm{T}_{3}=\mathrm{T}_{1}+25 \% \mathrm{NP}$ & 93 & 14.3 & 94 & 9.6 & 100 & 14.1 & 89 & 9.6 \\
\hline $\mathrm{T}_{4}=\mathrm{T}_{1}+25 \% \mathrm{NK}$ & 91 & 15.6 & 116 & 8.5 & 104 & 16.6 & 97 & 10.4 \\
\hline $\mathrm{T}_{5}=\mathrm{T}_{1}+25 \% \mathrm{PK}$ & 86 & 14.3 & 96 & 9.2 & 98 & 14.0 & 90 & 9.6 \\
\hline $\mathrm{T}_{6}=\mathrm{T}_{1}+25 \% \mathrm{NPK}$ & 103 & 17.4 & 133 & 10.6 & 111 & 19.8 & 109 & 10.0 \\
\hline $\mathrm{T}_{7}=75 \%$ of $\mathrm{T}_{1}$ & 74 & 12.2 & 89 & 6.4 & 68 & 10.3 & 68 & 7.9 \\
\hline $\mathrm{T}_{8}=$ Control & 50 & 7.4 & 47 & 4.7 & 45 & 07.7 & 44 & 4.6 \\
\hline
\end{tabular}

- $\quad$ STB $=$ Same as in Table $2 \mathrm{a}$

Table 4b. Effects of fertilizers on nutrient uptake $\left(\mathrm{kg} \mathrm{ha}^{-1}\right)$ by T. aman rice (Binadhan-7) during Kharif-II season, 2011 at Kaligonj, Lalmonirhat and Pirgonj, Rangpur

\begin{tabular}{|c|c|c|c|c|c|c|c|c|}
\hline \multirow[t]{2}{*}{ Treatments } & Kaligonj (Lalmonirhat) & Pirgonj (Rangpur) & \multirow[b]{2}{*}{$\mathrm{K}$} & \multirow[b]{2}{*}{$S$} & \multirow[b]{2}{*}{$\mathrm{N}$} & \multirow[b]{2}{*}{$\mathrm{P}$} & \multirow[b]{2}{*}{ K } & \multirow[b]{2}{*}{$\mathrm{S}$} \\
\hline & $\mathrm{N}$ & $\mathrm{P}$ & & & & & & \\
\hline $\mathrm{T}_{1}=\left(100 \% \mathrm{STB}^{*}\right)$ & 61 & 8.3 & 75 & 5.0 & 79 & 11.5 & 75.4 & 6.6 \\
\hline $\mathrm{T}_{2}=\mathrm{T}_{1}+25 \% \mathrm{~N}$ & 64 & 11.2 & 74 & 5.9 & 89 & 12.5 & 89.5 & 7.2 \\
\hline $\mathrm{T}_{3}=\mathrm{T}_{1}+25 \% \mathrm{NP}$ & 67 & 10.9 & 60 & 6.2 & 76 & 10.7 & 78.5 & 7.4 \\
\hline $\mathrm{T}_{4}=\mathrm{T}_{1}+25 \% \mathrm{NK}$ & 73 & 11.0 & 92 & 5.5 & 86 & 12.1 & 93.8 & 6.8 \\
\hline $\begin{array}{l}\mathrm{T}_{5}=\mathrm{T}_{1}+25 \% \mathrm{PK} \\
\mathrm{T}_{6}=\mathrm{T}_{1}+25 \%\end{array}$ & 61 & 9.6 & 77 & 5.3 & 76 & 12.4 & 74.8 & 6.6 \\
\hline NPK & 77 & 11.7 & 101 & 6.3 & 92 & 14.0 & 98.3 & 7.2 \\
\hline $\mathrm{T}_{7}=75 \%$ of $\mathrm{T}_{1}$ & 53 & 7.8 & 68 & 5.1 & 61 & 10.9 & 73.3 & 5.8 \\
\hline $\mathrm{T}_{8}=$ Control & 38 & 6.8 & 43 & 3.3 & 47 & 6.6 & 53.5 & 3.8 \\
\hline
\end{tabular}

* STB $=$ Same as in Table 2a

\section{Economics of fertilizers use}

The results of partial budget analysis of T.aman rice (Table 5a to Table 5b) demonstrated that the highest net benefit of Tk. ha ${ }^{-1} 85,598,78,619,58,308$ and 72,532 was obtained in $\mathrm{T}_{6}$ treatment followed by Tkha $^{-1} 76,348$ in $\mathrm{T}_{4}$ treatment, 71,100 in $\mathrm{T}_{3}$ treatment, 54,192 in $T_{3}$ treatment and 68,247 in $\mathrm{T}_{2}$ treatment at Birgonj, Dinajpur; Debigong, Panchagarh; Kaligong, Lalmonirhat and Pirgonj, Rangpur. Another attempt also been made to find out the marginal benefit cost ratio (MBCR) against the treatments, which is also shown in Table 5a to Table 5b. The highest MBCR of 5.40, $3.75,2.20$ and 3.84 was obtained in $\mathrm{T}_{6}$ treatment followed by 4.25 in $\mathrm{T}_{4}$ treatment, 2.89 in $\mathrm{T}_{2}$ treatment, 1.73 in $\mathrm{T}_{3}$ treatment and 3.52 in $\mathrm{T}_{2}$ treatment at Birgonj, Dinajpur; Debigong, Panchagarh; Kaligong, Lalmonirhat and Pirgonj, Rangpur respectively.

Table 5a. Partial budget analysis for fertilizer use in T. aman rice (Binadhan-7) during Kharif-II season, 2011 at Birgonj, Dinajpur and Debigonj, Panchagar

\begin{tabular}{lcccccccccc}
\hline \multirow{2}{*}{ Treatment } & \multicolumn{4}{c}{ Birgong, Dinajpur } & \multicolumn{5}{c}{ Debigong, Panchagarh } \\
\cline { 2 - 11 } & Gross return & $\begin{array}{c}\text { Fert. } \\
\text { cost }\end{array}$ & Net return & $\begin{array}{c}\text { Marginal } \\
\text { return }\end{array}$ & MBCR & $\begin{array}{c}\text { Gross } \\
\text { return }\end{array}$ & $\begin{array}{c}\text { Fert. } \\
\text { cost }\end{array}$ & $\begin{array}{c}\text { Net } \\
\text { return }\end{array}$ & $\begin{array}{c}\text { Marginal } \\
\text { return }\end{array}$ & MBCR \\
\cline { 2 - 11 } & & \multicolumn{4}{c}{ Tk. ha $^{-1}$} \\
\hline $\mathrm{T}_{1}=\left(100 \% \mathrm{STB}^{*}\right)$ & 63480 & 5927 & 57553 & 11233 & 1.90 & 67350 & 5952 & 61398 & 10248 & 1.72 \\
$\mathrm{~T}_{2}=\mathrm{T}_{1}+25 \% \mathrm{~N}$ & 71420 & 6647 & 64773 & 18453 & 2.78 & 70530 & 6705 & 63825 & 12675 & 1.89 \\
$\mathrm{~T}_{3}=\mathrm{T}_{1}+25 \% \mathrm{NP}$ & 81550 & 6872 & 74678 & 28358 & 4.13 & 78030 & 6930 & 71100 & 19950 & 2.88 \\
$\mathrm{~T}_{4}=\mathrm{T}_{1}+25 \% \mathrm{NK}$ & 83420 & 7072 & 76348 & 30028 & 4.25 & 70180 & 7106 & 63074 & 11924 & 1.68 \\
$\mathrm{~T}_{5}=\mathrm{T}_{1}+25 \% \mathrm{PK}$ & 79420 & 6552 & 72868 & 26548 & 4.05 & 71920 & 6577 & 65343 & 14193 & 2.16 \\
$\mathrm{~T}_{6}=\mathrm{T}_{1}+25 \% \mathrm{NPK}$ & 92870 & 7272 & 85598 & 39278 & 5.40 & 85950 & 7331 & 78619 & 27469 & 3.75 \\
$\mathrm{~T}_{7}=75 \%$ of $\mathrm{T}_{1}$ & 60380 & 4445 & 55935 & 9615 & 2.16 & 59880 & 4464 & 55416 & 4266 & 0.96 \\
$\mathrm{~T}_{8}=$ Control & 46320 & 0 & 46320 & - & - & 51150 & 0 & 51150 & - & - \\
\hline${ }^{*} \mathrm{~S}$
\end{tabular}

* STB = Same as in Table 2a 
Table 5b. Partial budget analysis for fertilizer use in T. aman rice (Binadhan-7) during Kharif-II season, 2011 at Kaligonj (Lalmonirhat) and Pirgonj (Rangpur)

\begin{tabular}{|c|c|c|c|c|c|c|c|c|c|c|}
\hline \multirow[t]{3}{*}{ Treatment } & \multicolumn{5}{|c|}{ Kaligong (Lalmonirhat) } & \multicolumn{5}{|c|}{ Pirgonj (Rangpur) } \\
\hline & Gross return & $\begin{array}{c}\text { Fert. } \\
\text { cost }\end{array}$ & Net return & $\begin{array}{c}\text { Marginal } \\
\text { return }\end{array}$ & MBCR & $\begin{array}{l}\text { Gross } \\
\text { return }\end{array}$ & $\begin{array}{c}\text { Fert. } \\
\text { cost }\end{array}$ & $\begin{array}{c}\text { Net } \\
\text { return }\end{array}$ & $\begin{array}{c}\text { Marginal } \\
\text { return }\end{array}$ & $\begin{array}{l}\mathrm{MB} \\
\mathrm{CR} \\
\end{array}$ \\
\hline & \multicolumn{10}{|c|}{ Tk. ha ${ }^{-1}$} \\
\hline $\mathrm{T}_{1}=(100 \% \mathrm{STB} *)$ & 52160 & 5817 & 46343 & 3763 & 0.65 & 66950 & 5772 & 61178 & 15828 & 2.74 \\
\hline $\mathrm{T}_{2}=\mathrm{T}_{1}+25 \% \mathrm{~N}$ & 58100 & 6537 & 51563 & 8983 & 1.37 & 74750 & 6503 & 68247 & 22897 & 3.52 \\
\hline $\mathrm{T}_{3}=\mathrm{T}_{1}+25 \% \mathrm{NP}$ & 60920 & 6728 & 54192 & 11612 & 1.73 & 70240 & 6728 & 63512 & 18162 & 2.70 \\
\hline $\mathrm{T}_{4}=\mathrm{T}_{1}+25 \% \mathrm{NK}$ & 59020 & 6937 & 52083 & 9503 & 1.37 & 73440 & 6853 & 66587 & 21237 & 3.10 \\
\hline $\mathrm{T}_{5}=\mathrm{T}_{1}+25 \% \mathrm{PK}$ & 53600 & 6442 & 47158 & 4578 & 0.71 & 69790 & 6347 & 63443 & 18093 & 2.85 \\
\hline $\mathrm{T}_{6}=\mathrm{T}_{1}+25 \% \mathrm{NPK}$ & 65470 & 7162 & 58308 & 15728 & 2.20 & 79610 & 7078 & 72532 & 27182 & 3.84 \\
\hline $\mathrm{T}_{7}=75 \%$ of $\mathrm{T}_{1}$ & 49030 & 4663 & 44367 & 1787 & 0.38 & 56100 & 4329 & 51771 & 6421 & 1.48 \\
\hline $\mathrm{T}_{8}=$ Control & 42580 & 0 & 42580 & - & - & 45350 & 0 & 45350 & - & - \\
\hline
\end{tabular}

$* \mathrm{STB}=$ Same as in Table $2 \mathrm{a}$

\section{Conclusion}

The highest yield, nutrient uptake and net benefit was found in treatment $\mathrm{T}_{6}\left(\mathrm{~T}_{1}+25 \% \mathrm{NPK}\right)$ at all of the four locations under the study. Based on most profitable treatments, fertilizer doses of $\mathrm{N}_{80} \mathrm{P}_{8} \mathrm{~K}_{40} \mathrm{~S}_{8} \mathrm{Zn}_{1}$ in Birgonj, Dinajpur; $\mathrm{N}_{84} \mathrm{P}_{8} \mathrm{~K}_{40} \mathrm{~S}_{6} \mathrm{Zn}_{1}$ in Debigonj, Panchagarh; $\mathrm{N}_{80} \mathrm{P}_{8} \mathrm{~K}_{40} \mathrm{~S}_{6} \mathrm{Zn}_{1}$ in Kaligonj, Lalmonirhat and $\mathrm{N}_{81} \mathrm{P}_{8} \mathrm{~K}_{35} \mathrm{~S}_{8} \mathrm{Zn}_{1}$ in Pirgonj, Rangpur could be recommended for higher yield of Binadhan7 rice in North-West Bangladesh.

\section{Acknowledgement}

The authors gratefully acknowledged the financial support for this study under a Coordinated Project on Soil Fertility and Fertilizer Management for Crops and Cropping Patterns: BINA component of Sponsored Public Goods Research (SPGR), PIUBARC, NATP: phase-1.

\section{References}

Bhuiyan, N. I.1993. Banlanced fertilization in maximizing yield with rice based cropping system. A paper presented in two day training workshop on "Yield maximizing with balanced fertilization with emphasis on potash" held at BINA, Mymensingh. April 28-29

Fageria N. K.; V. C. Baligar and C. A. Jounes. 1991. Growth and Mineral Nutrition of Field Crops. Marcel Dekker, Inc. New York, Besel. Hong Kong, pp 77-124

Annadurai, K.; Palaniappan, S. P.; Mabilamani, P. and Karimani, R. 2000. Split application of potassium on rice. Agril. Reviews, 21(2): 36-44

Gomez, K. A. and Gomez, A. A. 1984. Statistical procedures for agricultural research (second edition). An International Rice Research Institute Book. John Wiley \& Sons, Inc., USA.

Islam, M. S.; Akhter, M. M.; Rahman, M. S.; Banu, M. B. and Khalekuzzman, K. M. 2008. Effect of nitrogen and number of seedlings per hill on the yield and yield components of T. aman rice (BRRI Dhan 33). Inter. J. Sustainable Crop Produc., 3(3): 61-65

Jadhav, A. S.; Solunke, S. S.; Alse, U. N. and Dhoble, M. V. 2006. Growth and Yield contributing characters of upland basmati rice as influenced by irrigation and nitrogen. College of Agril. Marathwada Agril. Univ. Parbhani. India. J, Anal. Plant-Physiology, 20(I): 51-55

Nagarathna,T. K. and Prakasha, H. C. 2007. Synchronization of potassium supply in rice hybrids. Environ, Ecol., 266(special 3A): 967968

Prudante, J. A.; Sigua, G. C.; Kongchum, M. and Prudente, A. D. 2008. Improving yield and nutrient uptake potentials of japonica and indica rice varieties with $\mathrm{N}$ fertilization. World J. Agril. Sci., 4(3): 326-332

Rahman, M. H.; Ali, M. H.; Ali, M. M. and Khatun, M. M. 2007. Effect of different levels of nitrogen on growth and yield of transplant aman rice cv. BRRI dhan32. Inter. J. Sustain. Crop Produc., 2(1): $28-34$

Rahman, M. 2008. Efficiency of phosphate fertilizers of different sources on growth, $\mathrm{P}$ uptake and yield of boro rice. M. S. Thesis, Dept. Soil Sci., BAU, Mumensingh

Sayeeduzzaman, 2008. Effect of P and S on the growth and yield of BRRIdhan 29. M. S. Thesis, Dept. Soil Sci., BAU, Mymensingh

Singh, M. K.; Thakur, R.; Verma, U. N.; Upasani, R. R. and Pal, S. K. 2000. Effect of planting time and $\mathrm{N}$ on production potential of basmati rice cultivars in Bihar Plateau. Indian J. Agron., 45(2): 300-303

Uddin, M. 2008. Effect of different levels of S on the growth and yield of BRRI dhan 41.Dept. of Soil Sci., BAU, Mymensingh 